\title{
UKURAN KEABSAHAN KEPUTUSAN TATA USAHA NEGARA DALAM PERSPEKTIF HUKUM ADMINISTRASI
}

\author{
Akhmad Nikhrawi Hamdie \\ FISIP, Universitas Islam Kalimantan MAB (UNISKA) Banjarmasin \\ Email : nikhrawi888@gmail.com
}

\begin{abstract}
This study aims to determine the size of the decision of state business administrative legal perpectives. In connection with the above, a judge can set aside the lower norms that are the basis of the decision, in the sense that the judge can not use it as a measurement because it is considered contrary to higher regulations. Thus, the judge can apply the above regulation as a measurement tool for evaluating the disputed State Administrative Decree.

Likewise also if after the judge collects the facts and then finds, tests and believes that the making of the State Administration Decree was made with bad ethics and morals and does not carry out the general principles of good governance, then the judge can cancel the Administrative Decree.
\end{abstract}

Keywords : Adinisrative Law Of Administrative Legal Administration

\section{PENDAHULUAN}

Pada dasarnya pemerintah adalah sekelompk orang yang diberi suatu kekuasaan legal oleh masyarakat setempat untuk melaksnakan pengaturan atas interaksi yang terjadi dalam pergaulan masyarakat (baik antara individu dengan individu, individu dengan lembaga pemerintah, lembaga pemerintah dengan lembaga pemerintah, lembaga pemerintah dengan pihak swasta, pihak swasta dengan individu) untuk memenuhi kebutuhan dan keperluan hidupnya sehari-hari, sehingga interaksi dapat berjalan secara harmonis.

Pemerintah dalam berbagai referensi memiliki banyak arti. Sebagian ahli yang memberikan pengertian dalam arti luas, yaitu pemerintah menurut fungsinya dan ini berhubungan dengan doktrin Trias Politica. Doktrin ini kali pertama dikemukakan oleh John Locke (1632-1704) dan Montesquieu (1689-1755) dan pada taraf itu ditafsirkan sebagai pemisahan kekuasaan (sparation of powers) Dimaksud pemerintah menurut
Montesquieu adalah seluruh lembaga Negara yang biasa dikenal dan terdiri dari tiga kekuasaan yaitu yang pertama ; legislatif atau kekuasaan membuat undangundang (rule making function) ; kedua, eksekutif atau kekuasaan yang melaksanakan undnag-undang (rule application function) ; ketiga, yudikatif yaitu kekuasaan mengadili atas pelanggaran undang-undang (rule adjudication function) atau kekuasaan yang mengawasi pelaksanaan Undang-undang. Trias Politica adalah suatu prinsip normatif bahwa kekuasaan-kekuasaan itu sebaiknya tidak diserahkan kepada orang yang sama untuk mencegah penyalahgunaan kekuasaan oleh pihak yang berkuasa. Dengan demikian diharapkan hak-hak azasi warga Negara lebih terjamin. (Miriam Budiarjo: 1986:151)

Sehubungan Negara mengatur antara individu atau badan hukum dengan pemerintahan, maka apabila seorang atau Badan Hukum Perdata yang merasa 
kepentingannya dirugikan oleh suatu Keputusan tata Usaha Negara dapat mengajukan gugatan tertulis kepada pengadilan yang berwenang. Berisi tuntutan agar Keputusan Tata Usah Negara yang disengketakan tersebut batal atau tidak sah, dengan atau tanpa disertai tuntutan ganti rugi atau rehabilitasi.

Adapun dasar atau alasan-alasan yang dapat digunakan untuk menggugat berkenaan dengan tuntutan tidak sahnya atau dibatalkannya suatu Keputusan Tata Usaha Negara, ditentukan dalam pasal 53 ayat (2) Undang-undang Nomor 9 tahun 2004 tentang Perubahan Atas Undang-undang Nomor 5 tahun 1986 tentang Peradilan Tata usaha Negara meliputi:

a. Keputusan Tata Usaha Negara yang digugat itu berkenaan dengan Peraturan Perundang-undangan yang berlaku.

b. Keputusan Tata usaha Negara yang digugat itu bertentangan dengan asas-asas umum pemerintahan yang baik.

Bagaimana pula halnya dengan penjelasan Pasal 53 huruf $b$ dan c UU No. 5 tahun 1986 ? Apakah batasan atau ruang lingkupnya sama dengan huruf a diatas? Undang-undang ini tidak menyebutkan demikian menurut penjelasan pasal 53 ayat (2) huruf b masing-masing ini : Dasar pembatalan ini sering disebut "Penyalahgunaan wewenang". Apa batasan penyalahgunaan wewenang tersebut belum ada ketentuan aturan umumnya. Menurut Philipus M. Hadjon bahwa di Belanda melalui AROBnya menunjukan dasar ini jarang sekali digunakan karena sulit pembuktianya. Oleh karena itu, gugatan sering menggunakan dasar seperti tersebut dalam huruf a, (bertentangan dengan peraturan perundang-undangan). ( Philipus M. Hadjon; 1993:53)

Selanjutnya penjelasan huruf c, Undang-undang ini menyatakan : Bahwa dasar pembatalan ini sering disebut "larangan berbuat sewenang-wenang". Philipus M.Hadjon menyatakan : Batasan berbuat sewenang-wenang dalam hal inipun sulit diukur. Dalam perundang-undangan Belanda konsep sewenang-wenang tersebut digeser oleh konseo "Kennelijik onredelijk" (nyata-nyata tidak beralasan) yang lebih operasional.( Philipus M. Hadjon; 1993:7)

\section{HASIL DAN PEMBAHASAN}

\section{Alat Ukur Pada Hukum Tertulis Sebagai Suatu Peraturan}

Dalam membahas alat ukur untuk menilai keabsahan Tata Usaha Negara ini, banyak sumber yang bias dijadikan refernsi, salah satunya adalah pandangan dari Dwi Astuti yang menyatakan bahwa dari segi alat ukur rechtmatigheid Keputusan Tata Usaha Negara pada dasarnya ada dua alat ukur, yaitu :

1. Peraturan perundang-undangan (hukum tertulis)

2. Asas-asas umum pemerintahan yang baik (hukum Tidak Tertulis)

a. Peraturan Perundang-Undangan (Hukum Tertulis)

Penelaahan dan pengkajian terhadap peraturan perundang-udangan ini meliputi hal-hal :

1) Pengertian dasar

2) Penetapan Norma dalam Hukum Administrasi

3) Bentuk-bentuk penetapan norma yang bertingkat dalam hukum positip

4) Peraturan Perundang-undangan yang digunakan sebagai alat ukur penilaian.

Untuk itu memerlukan telaah lebih lanjut mengenai ukuran ini yang dapat dipahami bahwa dari permasalahan inilah munculnya permasalahan ke berikut dari dikeluarkannya sebuag Keputusan. Khususnya berkenaan dengan kekuatan hukum yang akhirnya berdimensi pada rasa keadilan dan nilai-nilai administrasi dari keputusan sebagai produk 
yang mencerminkan kinerja hukum administrasi yang ditetapkan oleh administrasi secara standar.

a) Pengertian Dasar

Apabila diperhatikan dari kepustakaan hukum, terutama kepustakaan Eropa Kontinental, apa yang dimaksud dengan peraturan perundang-undangan atau "wetten in materiele zin", atau "gestz in materiele wetten", maka peraturan perundang-undangan itu mengandung tiga unsur :

(1) Norma hukum (recht normen)

(2) Berlaku keluar (naar buiten werken) ; dan

(3) Bersifat umum dalam arti luas (algemeenheid in ruime zin ) (Hajon;1998: 17)

Dengan demikian, peraturan perundang-undangan pada hakekatnya ialah pembentukan norma-norma hukum yang berlaku keluar dan bersifat umum dalam arti luas. Norma hukum berarti dalam peraturan perundang-undangan memuat ketentuanketentuan, apabila dilihat dari sifatnya dapat berupa : perintah, larangan, pengizinan ataupun pembebasan. Berlaku keluar artinya ditujukan kepada warga masyarakat. Bersifat umum dalam pengertian ditujukan kepada orang atau sekelompok orang yang tidak tertentu.

Berdasarkan pengertian dan uraian diatas, persoalannya bagaimana bentuk norma-norma hukum yang bersifat umum dan berlaku keluar tersebut ? Hal ini berkaitan dengan bentuk-bentuk penetapan norma dalam hukum positip. Sebelum menguraikan hal ini, lebih dahulu diuraikan penetapan norma dalam hukum administrasi, dari uraian ini akan timbul gambaran bentuk penetapan norma yang umum dan berlaku keluar tersebut yang kemudian akan diuraikan pada bagian sub bab berikutnya.
b) Penetapan Norma Dalam Hukum Administrasi
Berbeda dengan penetapan norma dalam hukum perdata tertulis dan hukum pidana pada umumnya, pembuat Undangundang (wetgever) sudah dianggap cukup memenuhi kebutuhan, dalam bidang hukum administrasi pihak pembuat Undang-undang ternyata tidak begitu memegang peranan dalam penentuan norma-norma hukum untuk perbuatan-perbuatan manusia dalam kehidupan masyarakat.( Philipus M. Hadjon, 1993:15)

Pembentuk Undang-undang di bidang pengaturan cukup hanya menentukan langkah-langkah pertama, menentukan norma-norma sementara, atau pokok-pokok saja. Kepada pembuata norma-norma tingkat yang lebih rendah diserahkan untuk pengaturannya lebih lanjut sampai kepada keputusan, karena pembuat peraturan terakhir ini lebih dekat dengan perwujudan dalam praktek kehidupan sehari-hari.

Undang-undang yang bersifat administratif kebanyakan memuat ketentuan-ketentuan mengenai prosedur, jadi hukum formal, sedangkan ketantuanketantuan hukum yang bersifat materiil yang harus ditaati oleh masyarakat kebanyakan hanya mengandung beberapa hal yang sangat umum sifatnya, jadi norma-norma materiilnya justru harus diatur lebih lanjut pada tingkatan-tingkatan yang lebih rendah. Dengan demikian, jelas bahwa pembuat Undang-undang itu hanya menentukan kerangkanya, sedangkan penentuan normanorma materiil selanjutnya oleh macammacam tingkatan badan atau Pejabat Tata Usaha Negara. Tentang mengapa penentuan norma-norma dalam hukum administrasi dilakukan secara bertingkat, hal ini ada beberapa alasan :

(1) Keseluruhan dari norma-norma hukum administrasi banyak jumlahnya yang tidak mungkin masing-masing harus diatur dalam suatu undang-undang formal yang dibentuk oleh Presiden dan DPR.

(2) Norma-norma administratif itu harus diselesaikan dengan keadaan- 
keadaan yang berubah serta yang ada sangkut pautnya dengan kemajuan dan perkembangan teknologi. Hal ini tidak mungkin pembuat Undang-undang dapat menggambarkan dan mengikuti perkembangan.

(3)

Pengaturan lebih lanjut sering memerlukan kemampuan dibidang teknis yang lebih mendetail atau mengenai perincian-perincian segi administrative dan teknis yang serba pelik, sehingga tidak mungkin untuk membebani pembentuk undang-undang dengan tugas-tugas demikian ini oleh karenanya lebih tepat pengaturannya diserahkan pada tingkatan-tingkatan yang lebih rendah

(4)

Sering terjadi menghadapi suatu keadaan yang kongkrit, karena kejadian-kejadian dalam praktek sangat bervariasi. Apakah sautu izin membangun itu dapat diberikan ?, apakah izin itu dalam kerangka UUG atau Undang-undang lainnya? Perbuatan yang diijinkan tersebut harus tunduk pada ketentuan-ketentuan yang mana ? Semua masalah ini mengenai persoalanpersoalan yang harus dilihat hal demi hal. Dimana normanya baru dapat ditentukan pada peraturan yang lebih rendah, sampai pada Keputusan Tata Usaha Negara. (Dwi Astuti; 2001:68)

Dalam kaitannya dengan alasan ini maka dalam lapangan Hukum administrasi sampai sekarang ini belum ada suatu kodifikasi seperti halnya dengan Hukum privat atau Hukum pidana. Menurut Philipus M.Hadjon, ada dua sebab sukar untuk mengadakan kodifikasi hukum administrasi :

(1) Hukum administrasi itu tumbuh secara sektoral, karena latar belakang yang demikian, saat ini sulit sekali mengadakan kodifikasi hukum administrasi sektoral.

(2) Dalam hukum administrasi dikenal asas "rechmatig". Dengan asas ini setiap tindakan pemerintahan selalu dianggap "rechmatig" sampai ada pembatalan. Asas ini dianut dalam hukum administrasi kita (Pasal 67 UU Nomor : 5 Tahun 1986)

Uraian dan alasan-alasan yang dikemukakan di atas, jelas menunjukan bahwa penetapan norma dalam hukum adminsitrasi itu bertingkat. Hal ini merupakan salah satu ciri khas dari hukum administrasi. Persoalannya, bagaimanakah bentuk-bentuk penetapan norma yang bertingkat tersebut dalam hukum positif ?

c) Bentuk-bentuk Penetapan Norma Dalam Hukum Positif

Norma adalah sarana yang dipakai oleh masyarakat untuk menertibkan, menuntut dan mengarahkan tingkah laku angota masyarakat dalam hubungannya satu sama lain. Untuk bias menjakankan fungsinya yang demikian itu, maka diperlukan unsure sebagai kekuatan lain yakni kekuatan yang bersifat memaksa. Paksaan ini diperuntukan kepada seluruh anggota masyarakat tanpa kecuali, dengan tujuan agar mereka mematuhinya. Kekuatan memaksa ini merupakan cirri yang menonjol, bahkan untuk dapat dipatuhi maka dibutuhkan ancaman atau sanksi. Adanya cirri dan unsure paksaan tersebut dilingkungan kelompok masyarakat yang berbeda sangat dimungkinkan timbulnya unsur paksaan maupun bentuk sanksi yang berlainan. Artinya hal ini tentunya dipengaruhi oleh budaya, tatanan social masing-masing, sehingga setiap kelompok masyarakat itu akan mencari cara, bentuk dan jalannya sendiri yang dianggap sesuai untuk memaksa anggota masyarakat berbuat seperti yang diinginkan.

Dalam hal ini menurut John Austin, sebagaimana dikutif oleh Prof.Dr.Satjipto Rahardjo,S.H menyatakan bahwa, Yang sesungguhnya disebut hukum adalah suatu jenis perintah.tetapi, karena ia disebut perintah, maka setiap hukum yang 
sesungguhnya, mengalir dari datu sumber yang pasti...apabila suatu perintah dinyatakan atau diumumkan, atau pihak menyatakan suatu kehendak agar pihak lain menjalankan atau mebiarkan itu dijalankan ..... (Friedmann, $1953: 152$ )

Sebagaimana diketahui wewenang untuk melaksanakan keputusan pemerintah itu sebagian besar memang terdiri dari macam-macam instansi yang berbeda dilingkungan pemerintahan di bawah Pejabat Tata usaha Negara. Hal ini berarti wewenang menyelenggarakan pemerintahan tidak saja berada pada Presiden, akan tetapi juga ada pada Badan atau Pejabat Tata Usaha Negara lainnya sampai pada ditingkat daerah. Kewenangan penentuan norma dalam hukum administrasi pertama-tama dilakukan oleh Badan Pembuat Undangundang (Presiden dan DPR) namun, norma dari Undang-undang sendiri belum bias diterapkan secara langsung kepada masalah yang dihadapi. Dalam kebanyakan hal, pembuat UU lalu menyerahkan kepada Badan atau Pejabat Tata Usaha Negara lainnya untuk mengatur lebih lanjut.

Sebagai contoh peraturan-peraturan yang berhubungan dengan izin usaha industri, mulai dari Undang-undang Nomor : 5 tahun 1984 tentang Perindustrian, dijabarkan kedalam berbagai Peraturan Pemerintah,keputusan Presiden, Keputusan Menteri, sampai kepada bentuk Peraturan Daerah dan Keputusan Kepala Daerah. Hal demikian menunjukkan bentuk-bentuk penetapan norma-norma dalam hukum positip disamping Undang-undang juga terdapat peraturan-peraturan tingkat yang lebih rendah dari undang-undang sampai kepada keputusan. Dengan adanya berbagai macam bentuk norma-norma tersebut, persoalannya adalah peraturan perundangundangan yang manakah yang akan digunakan sebagai alat ukur untuk menilai keabsahan Keputusan Tata Usaha Negara oleh hakim Peradilan Tata Usaha Negara? d) Peraturan Perundang-undangan Yang digunakan sebagai Alat Ukur Penilaian

Di dalam hal Peraturan Perundangundangan Yang digunakan ebagai alat ukur Penilaian Oleh Hakim Peradilan Tata Usaha Negara, maka sebagaimana telah dijealskan pada paragraph tentang pengertian dasar, bahwa peraturan perundang-undangan adalah penetapan norma yag berlaku kekuar dan bersifat umum dalam arti luas, normanorma tersebut bertingkat sifatnya dapat berupa undang-undang PP, Keppres, Permen, Perda, dan Keputusan Kepala Daerah. Persoalannya adalah peraturan perundang-undangan mana yang dapat digunakan sebagai alat ukur penilaian oleh hakim Peradilan Tata Usaha Negara ? Penelaahan hal ini perlu kiranya berpaling kepada Tap MPRS No. XX/MPRS/1996 tentang Tertib Hukum dan Tata urutan Peraturan Perundang-undangan RI Tap MPRS No. XX/MPRS/1966 yang sudah dicabut dan disempurnakan dengan Tap No.III/MPR/2000 tentang Sumber Hukum dan Tata urutan peraturan Perundangan Republik Indonesia dapat memberikan gambaran fungsi hubungan dan kedudukan peraturan perundang-undangan satu dengan lainnya, dengan demikian dapat memberikan petunjuk alat ukur dari peraturan perundangundangan yang dapat digunakan sebagai penilaian oleh hakim terhadap keabsahan suatu keputusan (baschikking)

Ketetapan

MPR-RI No.III/MPR/2000, menetapkan bahwa jenis dan hierarki Peraturan perundang-undangan itu, ialah :

(1) UUD 1945

(2) Ketetapan MPR

(3) Undang-undang/PERPU

(4) Peraturan Pemerintah

(5) Keppres/Peraturan Presiden

(6) Peraturan Daerah

Tata urutan Peraturan Perundangundangan menunjukkan tingkatan-tingkatan norma, yang disebutkan terlebih dahulu 
mempunyai kedudukan lebih tinggi dari norma yang disebut belakangan. Jenis Peraturan Perundang-undangan tersebut di atas, diakui keberadaannya dan mempunyai kekuatan hukum mengikat sepanjang diperintahkan oleh peraturan Perundangundangan yang lebih tinggi. Tingkatantingkatan tersebut di dalam setiap tata hukum menghendaki tertib hukumyang baik, teorinya mempunyai konsekuensi hukum pula yaitu peraturan yang tingkatannya lebih rendah tidak boleh mengandung materi yang bertentangan dengan materi yang dimuat dalam suatu peraturan yang lebih tinggi.

Permasalahan yang dihadapi karena norma-norma tersebut bertingkat sifatnya, manakah yang dijadikan sebagai alat ukur, apakah UUD, Tap MPR, UU, PP Keppres atau Peraturan Pelaksanaan bawah lainnya? Menganalisa permasalahan tersebut berdasarkan teori ilmu hukum ; suatu peraturan yang mengatur sesuatu permasalahan tidak boleh bertentangan dengan peraturan yang lebih tinggi tingkatannya (lex superior derogate legi inferiori) Hal ini menunjukkan, apakah hakim menggunakan alat ukur UUD,UU, Peraturan Pemerintah, Keppres atau Peraturan pelaksanaan di bawah lainnya tergantung kepada peraturan mana yang dialnggar dan berlaku sebagai dasar atau landasan dari keputusan (beschikking) tersebut.

Apabila berbagai tingkatan norma kita kaitkan dengan teori "stufenbau" Han Kelsen, sahnya suatu pembentukan hukum oleh instansi yang lebih rendah tergantung pada ekstensi lembaga yang lebih tinggi. Disamping itu, berlakunya suatu norma dalam system norma hukum adalah relative dan bergantung pada norma yang lebih tinggi yang membentuk dan menentukan daya lakunya. Dengan demikian, pembentukan norma peraturan perundangundangan bawahan senantiasa harus sejalan dan searah perundang-undangan yang lebih tinggi. Artinya tidak boleh bertentanga dengan materi yang lebih tinggi. Pembentukan suatu Undang-undang misalnya, harus sejalan dan searah dengan norma aturan dasar (Undang-undang Dasar) dan begitu pula norma-norma aturan di bawah Undang-undang umpamanya PP, Keppres, Kepmen, Instruksi Menteri, dan lain-lain harus searah dan sejalan dengan Undang-undang Persoalannya, apakah proses penjelmaan suatu peraturan perundang-undangan misalnya saja PP yang dibentuk oleh Presiden (Pasal 2 ayat (2) UUD 1945) telah sesuai dan searah berdasarkan peraturan perundang-undangan yang diatasnya ? Suatu peraturan perundang-undangan kadang-kadang dapat bertentangan dengan peraturan perundangundangan di atasnya dalam arti materiil atau kewenangan. Suatu contoh, Peraturan Pemerintah Nomor : 10 Tahun 1983 tentang izin Perkawinan dan perceraian bagi Pegawai Negeri Sipil yang masih berlaku dengan beberapa perubahan ketentuan dalam pasal-pasalnya berdasarkan PP Nomor :45 tahun 1990 tentang Perubahan Atas PP Nomor : 10 tahun 1983 Izin Perkawinan dan Perceraian bagi Pegawai Negeri Sipil. Latar belakang dikelaurkannya PP Nomor : 10 tahun 1983 dapat diketahui dari konsiderannya, yang menyatakan bahwa permohonan izin perceraian tersebut atas dasar PP Nomor : 10 tahun 1983, karenanya Pegawai Negeri yang bersangkutan mengajukan gugatan ke PTUN agar keputusan itu batal/tidak sah karena bertentangan dengan UU Nomor : 1 Tahun 1974. Persoalannya, peraturan mana yang dijadikan oleh hakim sebagai alat ukur penilaian atas keputusan (Beschikking) itu ?

Menelaah permasalahan tersebut di atas, pertama-tama yang dilakukan oleh hakim menilai dasar dari kewenangan penolakan tersbut, dalam arti aoakah keputusan itu bertentangan atau tidak dengan peraturan dasarnya (PP Nomor : 10 
Tahun 1983) Ketentuan pasal 7 ayat (2) Peraturan Pemerintahan ini dirumuskan : "ijin untuk bercerai karena alasan istri mendapat cacat badan atau penyakit dengan akibat tidak dapat menjalankan kewajibannya sebagai istri tidak diberikan oleh pejabat " ini berarti pejabat tersebut berwenang untuk tidak memberikan izin karena alasana istri mendapat penyakit atau cacat badan. Apabila peraturan ini yang hanya digunakan sebagai dasar penilaian oleh hakim, maka konsekuensinya keputusan tentang penolakan izin perceraian tersebut adalah sah. Persoalan apakah hakim hanya dapat menilai dengan menggunakan alat ukur peraturan dasar yang dijadikan keputusan penolakan tersebut ? Jawabnya tidaklah demikian, karena hakim juga harus melihat peraturan yang ada di atasnya dalam hal ini UU Nomor : 1 Tahun 1974.

Apabila dilihat dari segi hirarkhis atau tata susunan norma, maka yang dibentuk kedudukannya lebih rendah dari pada norma yang membentuk dan karena itu norma tersebut tidak boleh bertentangan dengan norma yang membentuknya yang mempunyai kedudukan lebih tinggi itu. Hirarkhis norma-norma ini berikut prinsip legitimasi yang diberikannya, menyebabkan ketentuan-ketentuan yang digariskan oleh suatu norma yang lebih tinggi merupakan ketentuan yang harus diikuti oleh norma yang lebih rendah.

Selain itu sesuai dengan asas perundang-undangan "lex Superior derogate legi inferiori" yaitu suatu peraturan yang lebih rendah tingkatannya tidak boleh bertentangan dengan peraturan yang lebih tinggi. Asas ini mengandung konsekuensi, peraturan yang lebih tinggi tidak dapat diubah atau duhapus oleh peraturan yang lebih rendah, serta isi peraturan rendahnya tidak boleh bertentangan dengan isi peraturan atasnya, kalau hal ini terjadi hakim dapat mengenyampingkan peraturan yang lebih tinggi tingkatannya.
Permasalahannya, apakah dengan demikian peraturan yang lebih rendah tersebut menjadi batal atau tidak sah ? jawabannya tentu tidak demikian, karena hakim PTUN tidak berwenang untuk menyatakan sah tidaknya Peraturan perundang-undangan dibawah Undang-undang. Berdasarkan Pasal 26 ayat (1) UU Nomor : 14 Tahun 1970 tentang Ketentuan-ketentuan Pkok Kekuasaan kehakiman dan pasal 31 UU nomor 14 tahun 1985 sebagaimana dirubah dengan UU Nomor : 5 Tahun 2004 tentang Mahkamah Agung, yang berwenang menyatakan tidak sah peraturan perundangundangan dibawah Undang-undang mahkamah Agung karena alasan bertentangan dengan peraturan perundangundangan yang lebih tinggi. Ini berarti harus melalui prosedur pemeriksaan ditngkat Kasasi. Terlepas dari persoalan hak menguji material peraturan perundang-undangan dalam kaitannya dengan alat ukur penilaian, sesuai dengan azas " lex superior derogate leg inferior " maka hakim PTUN sedkitnya dapat mengenyampingkan peraturan yang lebih rendah itu, dalam pengertian hakim dapat untuk tidak menggunakan sebagai alat ukur penilaian karena bertentangan dengan peraturan yang lebih tinggi.

Dengan demikian jawaban peraturan mana yang digunakan sebagai alai ukur penilaian, karena PP Nomor : 10 tahun 1983 dilihat dari segi materinya dalam hal ini alasan-alasan untuk mengajukan perceraian adalah bertentangan dengan UU Nomor : 1 tahun 1974, maka oleh karenanya walaupun badan atau pejabat berdasarkan peraturan dasarnya bertentangan dengan Undangundang yang lebih tinggi, maka hakim dapat menilai keputusan itu bertentangan dengan peraturan yang diatasnya oleh karena itu peraturan yang digunakan sebagai alat ukur penilaian adalah UU Nomor : 1 tahun 1974, karena secara hirarkhis kedudukannya lebih tinggi dari peraturan dasar (Peraturan Pemerintah Nomor : 10 tahun 1983) 


\section{KESIMPULAN}

Keabsahan suatu Keputusan Tata Usaha Negara dapat dinilai oleh hakim dengan menggunakan alat ukur yaitu perundangundangan. Dalam menerapkan peraturan perudang-undangan sebagai laat ukur pada hakekatnya hakim dapat menggunakan semua peraturan-peraturan yang terkait dengan keputusan itu. Namun karena norma hukum administrasi bertingkat kadangkadang terdapat pertentangan antara peraturan yang lebih rendah dengan peraturan yang lebih tinggi dalam arti materiil atau kewenangan, sedangkan peraturan yang lebih rendah tersebut dijadikan sebagai dasar dari suatu keputusan. Dalam hal ini hakim harus berpegang kepada hirarki atau tata susunan norma yang lebih lebih rendah tergantung pada eksistensi lembaga yang lebih tinggi. Ini berarti berlakunya suatu norma dalam system norma hukum adalah relative ia tergantung pada norma yang lebih tinggi yang membentuk dan menentukan daya lakunya.

\section{SARAN}

1. Mengingat tidak terdapatnya keseragaman yang berkaitan dengan prosedur pembuatan suatu keputusan Tata Usaha Negara, maka perlu diadakan kodifikasi bidang hukum administrasi yang memuat ketentuan umum tentang tata cara pembentukan suatu keputusan Tata Usaha Negara.

2. Agar adanya pedoman bagi hakim dalam menerapkan asas-asas umum pemerintahan yang baik sebagai alat ukur penilaian dalam pertimbangan keputusannya, perlu segera dituangkan dalam pedoman dan petunjuk-petunjuk tertulis, yang disebarluaskan untuk diketahui dan dilaksanakan sebagaimana mestinya. 3.

\section{DAFTAR PUSTAKA}

Atang, Ranuwihardja, R. 1989. Hukum Tata Usaha Negara dan Peradilan Tata Usaha Negara di Indonesia, Bandung : Tarsito.

Atmosudirdjo, Prajudi. 1981. Hukum Administrasi Negara. Jakarta: Ghalia Indonesia. Arrasjid, Chainur. 2001. Dasar-Dasar I/mu Hukum. Jakarta : Sinar Grafika.

Asluti, Dwi. 1998. Karakter Keputusan Administrasi Dalam Dimensi Hukum Publik. Solo

Panepan Mukti.

Budiardjo, Miriam. 1986. Dasar-dasar Ilmu Politik. Jakarta : PT. Gramedia

Hadjon, Philipus M. 1993. Pengantar Hukum Administrasi Indonesia. Yogyakarta : UGM Press. , 1993. Pemerintahan Menurut Hukum. Surabaya : Yuridika. , 1994. Menuju Kod/kasi Hukum Administrasi. Bali : Universitas Udayana.

Indroharto. 1991. Usaha Memahami Undang-Undang Peradilan Tata Usaha Negara Buku I. Jakarta : Sinar Harapan. 1993. Usaha Memahami Undang-Undang Peradilan Tata Usaha Negara Buku II. Jakarta : Sinar Harapan. 